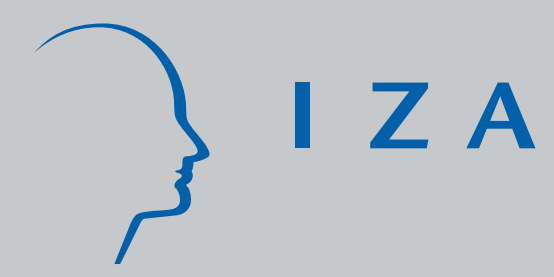

IZA DP No. 2101

Hispanic Self-Employment:

A Dynamic Analysis of Business Ownership

Magnus Lofstrom

Chunbei Wang

April 2006 


\title{
Hispanic Self-Employment: A Dynamic Analysis of Business Ownership
}

\author{
Magnus Lofstrom \\ University of Texas at Dallas \\ and IZA Bonn \\ Chunbei Wang \\ University of Texas at Dallas
}

\section{Discussion Paper No. 2101 \\ April 2006}

\author{
IZA
}

P.O. Box 7240

53072 Bonn

Germany

\author{
Phone: +49-228-3894-0 \\ Fax: +49-228-3894-180 \\ Email: iza@iza.org
}

\begin{abstract}
Any opinions expressed here are those of the author(s) and not those of the institute. Research disseminated by IZA may include views on policy, but the institute itself takes no institutional policy positions.

The Institute for the Study of Labor (IZA) in Bonn is a local and virtual international research center and a place of communication between science, politics and business. IZA is an independent nonprofit company supported by Deutsche Post World Net. The center is associated with the University of Bonn and offers a stimulating research environment through its research networks, research support, and visitors and doctoral programs. IZA engages in (i) original and internationally competitive research in all fields of labor economics, (ii) development of policy concepts, and (iii) dissemination of research results and concepts to the interested public.
\end{abstract}

IZA Discussion Papers often represent preliminary work and are circulated to encourage discussion. Citation of such a paper should account for its provisional character. A revised version may be available directly from the author. 


\section{ABSTRACT \\ Hispanic Self-Employment: A Dynamic Analysis of Business Ownership*}

This paper analyzes causes of the low self-employment rates among Hispanics, which are nearly half of non-Hispanic white self-employment rates. Relatively little is known of the reason for the lower entrepreneurship rates among Hispanics, the fastest growing ethnic group in the U.S. The paper analyzes the self-employment gap by studying self-employment entry and exits, which determine the observed self-employment rates, utilizing nationally representative longitudinal data, the 1996 panel of the Survey of Income and Program Participation (SIPP). The data reveals differences between Mexican-Hispanics and Hispanics not of Mexican descent, referred to as Other-Hispanics. While Mexican-Hispanics are less likely to enter self-employment, relative to whites, Other-Hispanics are more likely to start a business. The differences however, are relatively small but shown to be meaningful in explaining the white-Hispanic self-employment rate gap. The data show large differences in business survival rates between Hispanics and whites. Mexican-Hispanics are almost twice as likely to exit business ownership in a year compared to whites. Our results indicate that differences in education and financial wealth are important factors in explaining differences in entrepreneurship across groups. We also show that the lower self-employment entry rates among Mexican-Hispanics is due to lower entry rates into business ownership of firms in relatively high barrier industries. In fact, Hispanics are more likely to start-up a business in a low barrier industry than whites. Differences in the industry composition across groups is also discussed and analyzed as a determinant of differences in business survival rates.

JEL Classification: J15, J23

Keywords: self-employment, entrepreneurship, Hispanic

Corresponding author:

Magnus Lofstrom

University of Texas at Dallas

School of Social Sciences

P.O. Box 830688

GR 31

Richardson, TX 75083-0688

USA

Email: lofstrom@utdallas.edu

\footnotetext{
* We thank participants at the first Entrepreneurship Boot Camp, particularly Tim Bates, and seminar participants at Concordia University, Montreal for helpful comments as well as Rob Fairlie for providing SAS programming code for the nonlinear decomposition. Funding from the Ewing M. Kauffman foundation is greatly appreciated.
} 


\section{Introduction}

A major concern to U.S. policy makers is the relative lack of success of AfricanAmericans and Hispanics in the U.S. labor market. Evidence of this can be seen in recent data, such as the 2002 March CPS, which indicate that average annual earnings among working age male Hispanics is roughly equal to the earnings of African-Americans, both slightly above \$25,000 and substantially below average earnings of whites and Asians, who on average earn approximately $\$ 45,000$ per year. These two minority groups also have substantially lower self-employment rates. The above data also show that for both African-Americans and Hispanics, the self-employment rate is around one-half of the self-employment rates of whites and Asians. If self-employment is an important tool to facilitate upward economic mobility, which is commonly believed (see for example Glazer and Moynihan, 1970 and Cummings, 1980), it is important to understand why certain minority groups, such as Hispanics, have relatively low self-employment rates and how well they do as entrepreneurs. Support of self-employment acting as an avenue to economic improvement for Hispanics is found by Fairlie (2004) who reports that earnings among self-employed Hispanics males grow faster than earnings among their wage/salary counterpart. Also of importance, given the large proportion of Hispanics who are foreign born, is Lofstrom’s (2002) finding that self-employed immigrants do significantly better in the U.S. labor market than wage/salary immigrants.

Up to now, research on Hispanic self-employment has not received the same attention as African-American entrepreneurship. Hispanics are of particular interest given the fact that this is the fastest growing ethnic group in the U.S., primarily fueled by immigration, and now represents almost 14 percent of the U.S. population, slightly 
greater than the proportion of non-Hispanics blacks (Statistical Abstracts of the U.S., 2006).

An unresolved question in the entrepreneurship literature is why Hispanics are less likely to be self-employed than other ethnic groups, such as whites. This paper extends and contributes to the existing entrepreneurship literature by analyzing the observed Hispanic self-employment gap, relative to non-Hispanic whites. Since the selfemployment rate is a function of the number of individuals who enter and exit selfemployment, it suggests that to adequately understand differences in business ownership, as well as entrepreneurial success or failure, research needs to also address the dynamic dimension of self-employment.

The paper is organized in the following way. In section 2 we review relevant entrepreneurship literature. Section 3 describes the data and variables while in Section 4 we present descriptive statistics and discuss differences, between Hispanics and nonHispanic whites. In Section 5 we present a business ownership entry/exit model while in Section 6 we present the empirical results as well as a decomposition of the effect of observable characteristics on the minority-white self-employment gap. Lastly, we conclude in Section 7.

\section{Previous Research}

In order to address the issue of the low Hispanic self-employment rate and to identify possible determinants, we build on the large entrepreneurship literature addressing the business ownership choice as well as research addressing minority-white self-employment gaps, particularly the black-white gap. 
The focus of a considerable body of the literature is the role of access to financial capital in business creation and whether liquidity constraints are binding. This is typically assessed by investigating whether own financial wealth impacts the decision to become a business owner, holding constant all other relevant factors. The majority of these studies do find evidence of binding liquidity constraints in business start-ups (e.g. Evans and Leighton, 1989; Evans and Jovanovic, 1989; Lindh and Ohlsson, 1996). A rare exception is Hurst and Lusardi (2004). Furthermore, Holtz-Eakin, Joulfaian and Rosen (1994a) find that greater assets, measured as inheritances, leads to higher probability of business survival, also suggesting that liquidity constraints are binding and not only affects business start-ups. Furthermore, Bates (1990) finds that owner educational background is a major determinant in business survival and financial capital structure of small business start-ups. Other factors linked to the business ownership decision are managerial ability (e.g. Jovanovic, 1982) risk aversion (e.g. Kihlstrom and Laffont, 1979), non-pecuniary benefits (e.g. Blanchflower and Oswald, 1998) and intergenerational links, such as parental wealth and entrepreneurship (Dunn and Holtz-Eakin, 2000).

Nor surprisingly, the above factors have also been linked to explaining the low self-employment rates among some minority groups such as African-Americans and Hispanics, or Latinos. Although differences in wealth, education and family structure across groups have been found to partly explain differences in self-employment rates (Fairlie, 1999 and Hout and Rosen, 2000) differences in parental entrepreneurship appears to explain a significant proportion of the gap. (Fairlie, 1999 and Hout and Rosen, 2000). Unfortunately, it is not clear what the policy recommendations are based on the findings of strong intergenerational links. Although it points towards returns to policies 
that do decrease the gap across generations. The fact that a substantial proportion of Hispanics are immigrants, and have not yet accumulated sufficient financial and human capital, as well as information, is also a contributor to the self-employment gap (Fairlie and Meyer, 1996).

Another potential factor explaining differences in business ownership is differential treatment in the credit market. Blanchflower, Levine and Zimmerman (2003) find that black-owned small businesses are about twice as likely to be denied credit and if approved pay a one percentage point higher interest rate than whites even after controlling for differences in creditworthiness and other factors and conclude that differences in credit availability is likely caused by discrimination. The credit constraints faced by certain minority groups are likely to impact the types of industry, and hence the industry composition, and the structure of the business, as maintained by Bates (1995).

The only existing research, to our knowledge, directly addressing the lower selfemployment rates among Hispanics by studying business entry and exits is a working paper by Fairlie and Woodruff (2005), who utilizes matched CPS data, and finds that differences in education and wealth are key factors in explaining the low selfemployment rates among Mexican-Americans. ${ }^{1}$ Our study addresses the heterogeneity among Hispanics, an issue raised by Bates (1990), by disaggregating Hispanics into two groups, Mexican-Hispanics and Other-Hispanics, as well as controlling for immigration status. Our nationally representative longitudinal data, the Survey of Income and Program Participation (SIPP), also has the advantage of following individuals over a four year period, as opposed to only one year possible utilizing CPS data, as well as more detailed

\footnotetext{
${ }^{1}$ Taniguchi (2002) analyzes women’s entry into self-employment but does not decompose ethnic or racial differences in self-employment rates. The study utilizes NLSY data and includes Hispanic women younger than 41.
} 
information regarding assets and business ownership. We also address the role of industry the entrepreneur chooses and operates within in explaining the Hispanic-white self-employment gap. The paper also evaluates the impact of differences in entry and exit rates on the observed business ownership gap between Hispanics and whites.

\section{Data}

The data utilized in this paper is derived from the 1996 panel of the Survey of Income and Program Participation (SIPP), covering a four year period from 1996 to 1999. The data is nationally representative, when appropriate weights are utilized, and includes information on socio-economic characteristics, geographic location, country of origin, year of arrival in the U.S., assets, asset income, industry, as well as business ownership.

The 1996 SIPP survey is a rotating panel made up of waves of data collected every four months for approximately 36,700 U.S. households. The 1996 panel over sampled low-income households and hence sampling weights will be used throughout our analysis. As with previous SIPP panels, each wave contains both core questions, common to each wave, and topical questions that are not updated in each wave. In addition to the key variables found in the core modules, we use information from two topical modules; immigration (which includes information on country of origin as well as year of arrival

collected in the $2^{\text {nd }}$ of the12 waves ) and assets and liabilities (containing wealth and asset data, collected each year in waves 3, 6, 9 and 12).

The sample utilized is restricted to Hispanic and non-Hispanic white males between the ages of 20 and 64 in the survey period. We divide Hispanics into two groups; 
Mexican-Hispanics and Other-Hispanics (the latter groups consistsing largely of Hispanics of Puerto Rican and Cuban descent). We do not restrict our sample to containing only full-time working individuals since a significant proportion of business entries and exits are from or to non-employment, which includes both unemployment as well as not in the labor force. Concentrating this specific research on males simplifies the analysis somewhat since male labor supply issues are arguably less complicated. Furthermore, we restrict our sample to males for whom immigration status and wealth information is available, as well as to individuals who are observed in at least two consecutive years. The latter restriction is necessary for our analysis of transitions in and out of self-employment, which is based on changes in year-over-year labor market state by panel wave. Furthermore, an individual is defined to be self-employed if he reported owning a business in the sample wave. The sample restrictions yield a sample of 140,734 observations, or 19,271 individuals.

\section{Descriptive Statistics}

Table 1 shows sample means by the above defined groups. The data shows, as previous research also indicates, that Hispanics have substantially lower annual earnings relative to whites. This does not appear to be largely due to fewer hours worked or lower employment rates among Hispanics since there seems to be no substantial differences in these across the groups. However, educational attainment among Hispanics is considerably lower, partially explaining the lower earnings. Among Mexican-Hispanics males, $42 \%$ have less than a high school diploma and only about $6 \%$ are college graduates. The respective proportions among Other-Hispanics and whites are $26 \%$ and 
$9 \%$ dropouts and $17 \%$ and $30 \%$ college graduates. Not surprisingly given the above observations, wealth and asset incomes are also lower among Hispanics, particularly among Mexican-Hispanics. Table 1 also shows that Hispanics are substantially less likely to be business owners compared to white. Approximately 8.5\% of Hispanics of Mexican origin in our sample report owning their own business, while $11.7 \%$ of Hispanics of nonMexican origin are business owners, and slightly more than $16 \%$ of whites are selfemployed.

We show sample statistics by ethnic group and whether the person owns a business or works in the wage/salary sector in Table 2 . Note that we have restricted the non-business owners in the sample used for Table 2 to wage/salary workers, i.e. it is conditional on employment. This is done since a motivation for the information provided in the table is to address observable differences, and differences in economic well-being, between wage/salary workers and entrepreneurs. Interestingly, the table shows that mean total annual earnings among both Hispanic groups are not dramatically different between wage/salary workers and business owners, and in fact somewhat lower for MexicanHispanics. Mean earnings of white entrepreneurs are on the other hand substantially higher than among white wage/salary workers. If however the success story among entrepreneurs is one of relatively few very successful business owners, comparison of mean outcomes creates a skewed picture, suggesting that a preferred summary statistics is the median. Table 2 reveals lower median earnings among the self-employed compared to wage/salary workers for all three groups.

Another issue in comparing earnings of wage/salary workers and the selfemployed as a measure of success, or economic well being, is that business owners may 
opt to re-invest portions of profits/earnings in their business instead of taking it out as salary, leading to, not necessarily higher earnings, but higher wealth. This suggests that financial wealth is also a relevant measure of the relative labor market success of entrepreneurs and wage/salary workers. Our data indicates that this may be of importance, since when we compare household wealth between business owners and workers, both mean and median wealth is significantly higher among the self-employed for both Hispanics and whites. ${ }^{2}$ Lastly, it should be noted that whether we compare mean or median earnings and wealth, both Hispanic groups earn less than whites and possess less wealth than whites.

\section{Self-employment Entry and Exit}

The lower business ownership rates among both Mexican-Hispanics and OtherHispanics relative to whites, 8.5, 11.7 and 16.1 percent respectively, is determined by differences in self-employment entry and exit rates across the groups. Table 3 shows the self-employment ratio (defined as the number of self-employed divided by the sample population) as well as the probability of entering self-employment at time t, conditional on non-business ownership at time t-1, where time t is measured in years. Similarly selfemployment exit rates are conditional movements from business ownership at time t-1 to non-business ownership at time t. ${ }^{3}$

\footnotetext{
${ }^{2}$ Wealth is defined as the sum of financial assets and equity in home, vehicle and owned business.

${ }^{3}$ The transition rates shown in Table 3 appear to be consistent with previous research on self-employment entry and exits. For example, Holtz-Eakin, Joulfaian and Rosen (1994a and 1994b) report four-year entry and exit transition rates, 1981-1985, based on administrative data of 6.8 percent and 28 percent respectively. These are quite similar to the sample period transition rates obtained with our definition of self-employment using the SIPP data with the above specified sample; about 8 percent and 32 percent respectively. Some of the differences are likely to be due to changes in self-employment since the 1980's and our sample selection.
} 
Table 3 shows that Mexican-Hispanics have both the lowest entry and the highest exit rates, 2.4 percent and 20.5 percent annual transition rates, suggesting that both contribute to the observed lower business ownership rates. Other-Hispanics are almost 1 percentage point more likely to enter self-employment each year than MexicanHispanics, while the self-employment entry rates among non-Hispanic whites are approximately 0.3 percentage points greater than the ones of Mexican-Hispanics. The differences between Hispanics and whites are however substantially greater in the selfemployment exit rates. Among Mexican-Hispanics entrepreneurs, 20.5 percent exit selfemployment annually while only slightly more than 11 percent of white business owners exit self-employment. The year-over-year exit rate for Other-Hispanics is 18.6 percent. Overall, these transition rates suggest that higher Hispanic business failure rates, or exits, are the main cause for the lower Hispanic business ownership rates. The table also shows that for all three groups, roughly 85 percent of the individuals who enter self-employment do so by leaving a wage/salary job. Furthermore, of the individuals who exit selfemployment, a substantial portion do so by either leaving the labor force or to enter unemployment in the subsequent year. This suggests that it is of some importance to not restrict the sample to individuals working full-time. It also suggests that entries and exits may be gradual movements in and out of business ownership.

It should be pointed out that even if the differences in business entry rates are relatively small, this does not imply that they are unimportant and/or that minorities do not face additional business start-up constraints. Firstly, small differences in entry rates may lead to substantial differences in the observed rates of business ownership, as discussed and demonstrated in the results section. Secondly, the relatively low 
educational attainment level of Hispanics is likely to restrict access to certain industries (such as professional services which includes physicians, dentists and lawyers) and may “push” Hispanic entrepreneurs into less selective, educationally speaking, industries. If industries that require relatively high schooling levels to enter also have relatively high business survival rates, we may not observe large differences in business start-up rates but average exit rates will be higher for Hispanics. Thirdly, If Hispanics enters certain types of less well funded businesses, or industries, because they face limited access to capital, we may expect this to reveal itself in higher business failure rates, even though the self-employment entry rates are not dramatically different. Clearly, it is quite challenging to address the latter issue, but the above discussion suggests that a closer look at industries is important in order to understand why Hispanics are less likely to be business owners than non-Hispanic whites.

The type of business ownership is also of interest and related to potential barriers to enter self-employment. The SIPP data contains information on what type of business the individual owns, as well as business equity. These characteristics are shown in Table 4, together with how long the business has been owned by the individual and business equity. The table shows that self-employed Mexican-Hispanics are substantially less likely to own an incorporated business than either of the other two groups. Furthermore, business equity is found to be lower among Hispanic owned businesses than white owned businesses. It is particularly low among Mexican-Hispanics, about $\$ 25,000$, compared to $\$ 54,000$ and close to $\$ 90,000$ for the Other-Hispanic group and whites respectively. Although, these observed characteristics may be the outcome of different selection into business ownership between minorities and whites (see e.g. Kawaguchi, 2005), they are 
also consistent with Hispanics facing additional capital constraints, relatives to whites, as well as group differences in educational attainment.

The distribution of industries entrepreneurs operate in also varies across the three groups. Table 5 shows the industry distribution for business owners, as well as mean years of schooling and business equity by these industries. The table shows that MexicanHispanics business owners are most likely to own a business in the construction industry, which is also an industry with relatively low educational attainment and business equity. The construction industry is also the most common industry to own a business among the other two groups, but by roughly 13 percentage points fewer business owners, about 33 percent among Mexican-Hispanics and approximately 20 percent of entrepreneurs in the other two groups. A large proportion of Non-Hispanic whites own a business in the professional services industry, slightly more than 16 percent. Only about 4 percent of Mexican-Hispanics own a business in this industry of the most highly educated entrepreneurs, where business owners have close to 18 years of schooling on average. Overall, it appears that Hispanics may be over-represented, relative to whites, in industries with lower educational attainment levels and business equity.

What causes the differences in business ownership industry distributions is not clear, but the data in the table suggests incorporating and analyzing the role of industries in the business transition models. Of course, we would expect that entrepreneurs belonging to a group with lower educational attainment would be more likely to operate in industries with lower schooling levels. Nonetheless, we address the issue in our analysis below. 


\section{Self-Employment Entry and Exit Model}

The objective of our study is to investigate the determinants of the low Hispanic self-employment rates by analyzing entry and/or exits into self-employment. To analyze differences in self-employment rates, it is useful to model the decision to enter and exit a business venture. One possibility is to assume that individuals choose to enter, or exit, self-employment based on expected utility in each state (e.g. self-employment, wage/salary work, unemployment or to not participate in the labor force), as well as constraints faced by the individual.

Let us assume that the utility function is a function of expected income, or earnings if working, $y_{\text {it }}^{\text {s-e }}$ for self-employment work and $y_{\text {it }}^{\mathrm{J}}$ for participating in state $\mathrm{J}$ (defined here as wage/salary work, unemployment or to not participate in the labor force and where $i$ and $t$ are indices for individual $i$ at time $t$ ), and that the function also indicates preferences for the characteristics of participation or work in the state, denoted $\mathbf{z}_{\mathrm{i}}$. Furthermore, earnings, or income, in each state will depend on a vector of observable characteristics, $\mathbf{X}_{i t}$, possible constraints faced by the individual, $\mathbf{v}_{i t}$, and unobserved characteristics $\varepsilon_{i t}$, which may represent random shocks to earnings or income opportunities. It also possible to allow $\mathbf{z}_{i}$ to include time invariant unobserved individual heterogeneity that affects earnings, such as ability and motivation. Assuming that individuals maximize expected utility, a person will choose self-employment if the expected utility from self-employment, denoted $E\left(u_{\mathrm{it}}^{\mathrm{s}-\mathrm{e}}\right)$, is greater than the expected utility in any of the other $\mathrm{J}$ states, represented here by $E\left(u_{\mathrm{it}}^{\mathrm{J}}\right)$. Expected utility in the $\mathrm{J}+1$ states can be defined as: 


$$
\begin{aligned}
& E\left(u_{i t}^{J}\right)=y_{i t}^{J}+\mathbf{z}_{i t}^{J} \lambda^{J}=\mathbf{X}_{i t} \beta^{J}+\mathbf{v}_{i t}^{J} \delta^{J}+\mathbf{z}_{i}^{J} \lambda^{J}+\varepsilon_{i t}^{J} \\
& E\left(u_{i t}^{s-e}\right)=y_{i t}^{s-e}+\mathbf{z}_{i}^{s-e} \lambda^{s-e}=\mathbf{X}_{i t} \beta^{s-e}+\mathbf{v}_{i t}^{s-e} \delta^{s-e}+\mathbf{z}_{i}^{s-e} \lambda^{s-e}+\varepsilon_{i t}^{s-e}
\end{aligned}
$$

where $\varepsilon^{J}$ and $\varepsilon^{s-e}$ may be assumed to be jointly normally distributed with mean zero and variances $\sigma_{J}^{2}$ and $\sigma_{s-e}^{2}$. Alternatively, as is done in our analysis, the disturbances may be assumed to follow a logistics distribution. An individual chooses self-employment at time $t$ if:

$$
I_{i t}^{*}=E\left(u_{i t}^{s-e}\right)-E\left(u_{i t}^{J}\right)>0, \text { for any state } \mathrm{J}
$$

Clearly the index function $I_{i t}^{*}$ is unobservable. However, from equations (1), (2) and (3) $I_{i t}^{*}$ can be defined as:

$$
\begin{aligned}
I_{i t}^{*}= & E\left(u_{i t}^{s-e}\right)-E\left(u_{i t}^{J}\right) \\
= & \mathbf{X}_{i t} \beta^{s-e}-\mathbf{X}_{i t} \beta^{J}+\mathbf{v}_{i t}^{s-e} \delta^{s-e}-\mathbf{v}_{i t}^{J} \delta^{J} \\
& +\mathbf{z}_{i}^{s-e} \lambda^{s-e}-\mathbf{z}_{i}^{J} \lambda^{J}+\varepsilon_{i t}^{s-e}-\varepsilon_{i t}^{J} \\
= & W_{i t} \pi+e_{i t}
\end{aligned}
$$

If we set $I=1$ if $I_{i t}^{*}>0$, if the individual is observed to have entered self-employment at time $t$, and $I=0$ if $I_{i t}^{*} \leq 0$, if the person decides not to start up a new business, then equation (4) can simply be seen as a probability model of entry into self-employment. In other words, the model can be seen as a conditional probability model where the person is observed to not be self-employed in the previous time period, i.e. at $t$-1. Similarly, conditioning on observing the person to be in self-employment at time $t$ - 1 , the model can represent the business ownership exit decision. 
Of interest here are the determinants and particularly their role in explaining the observed relatively low Hispanic self-employment rates. For example, differences in human capital and financial capital are likely to be determinants of the Hispanic-white self-employment gap. To address the endogeneity issue of wealth levels on selfemployment, in the sense that higher wealth levels may be the results of entrepreneurship and not the cause, we utilize one year lagged wealth and asset income in the estimated models. Differences in marital status, family composition, geographic location and the composition of U.S. born and foreign born individuals are also likely to have an impact on the observed rates of self-employment.

The entry and exit models estimated can be represented by the following, where $I_{i t}=1$ represents an observed transition, i.e. a decision to enter or exit self-employment:

$$
\operatorname{Prob}\left[I_{i t}=1\right]=\mathbf{X}_{i t} \beta+\mathbf{v}_{\mathrm{it}} \delta+e_{\mathrm{it}}
$$

where

$$
\begin{array}{ll}
\mathbf{X}_{i t}=\quad \begin{array}{l}
\text { Matrix containing observable characteristics such as age, } \\
\text { educational attainment, marital status, number of } \\
\text { children, immigrant status, years in residence in the U.S., } \\
\text { geographic location. }
\end{array} \\
\quad \begin{array}{l}
\text { Matrix containing controls for potential business ownership } \\
\text { constraints, or barriers, such as financial assets. }
\end{array}
\end{array}
$$

To assess the role of the above controls and characteristics in explaining the ethnic/racial self-employment gap the self-employment models will also be estimated separately by the three groups, Mexican-Hispanics, Other-Hispanics and whites. The estimates and the values of the observed characteristics are then utilized in a nonlinear 
Blinder-Oaxaca decomposition (such as Fairlie, 1999) to determine their contributions of each type of characteristic on the observed differences in self-employment entry or exit.

Clearly, potential business ownership constraints faced by minorities are typically not directly observable. However, they may manifest themselves in the choice of industry, or types of business, as discussed above. For example, if there are additional lending constraints faced by minorities, as suggested by Blanchflower, Levine and Zimmerman (2003), we would expect to see fewer minorities in financial capital intensive industries. As discussed above, however, some barriers to self-employment are observable. For example, given the substantial observed differences in educational attainment between Hispanics and whites, many Hispanics effectively do not have access to certain human capital intensive industries. This can, at least partially, be addressed by simply controlling for schooling levels. However, Hispanics' stock of human capital may be valued and/or perceived differently from non-Hispanics, suggesting that education may play different roles across ethnic/racial groups. Evidence of different roles of education in the U.S. labor market, in terms of schooling's impact on earnings, between immigrants and natives is found in Betts and Lofstrom (2000). Given the large proportion of immigrants among Hispanics, this is relevant to the self-employment decision, which is partially based on expected earnings. The above reasoning suggests that it is important to address the role of industries, which vary in the human and financial capital requirements, as argued by Bates (1995).

In the analysis below we attempt to tackle these issues by estimating multinomial logit models of self-employment entry. In this setting, we view the self-employment and industry choices as simultaneous. 
A practical restriction we face is that the number of individuals in the industries defined in Table 5 are in some cases small, particularly by race/ethnicity, making relatively precise estimation difficult. Instead, we define three industry categories based on human and financial capital requirements, or barriers, to enter the industry. Clearly, any classification into industry categories of entry difficulty, or barriers, is somewhat arbitrary. Nonetheless, to determine whether an industry is a low, medium or high barrier industry, we utilize the 1997 Annual Capital Expenditure Survey (ACES) to determine average fixed private capital by the 14 industries defined in Table 5 and the 2000 Census to determine entrepreneurs' educational attainment by industry. Based on the above data, we categorize Gardening/Landscaping, Construction, Retail trade and Repair services as low barrier industries since all these industries display relatively low average educational attainment levels (roughly around high school graduate or below) and average capital expenditures rank among the lowest. The medium barrier category consists of firms in Agriculture, Manufacturing, Transportation/Communications, Wholesale trade, Business services, Personal services and Entertainment/Recreation services. These are industries in which entrepreneurs typically have at least some college education and/or average capital expenditures are in the mid-range amongst our industries. The high barrier industry category consists of firms in the Finance/Insurance/Real estate, Professional/Related services or "Other" industries. According to the 2000 Census, more than 85 percent of entrepreneurs in the Finance/Insurance/Real estate and Professional/Related industries have some college education while the 1997 ACES data show that businesses in the Finance/Insurance/Real estate and Other industries have the highest average capital expenditures. 
Lastly, the increase in the number of choices also implies that the year-over-year probability an individual chooses a particular transition, or no transition, is rather small. Hence, for the multinomial logit models below, we focus on the four-year sample period transition probabilities, i.e. changes from first being observed to the last period being observed.

We show the sample period entry and exit rates separately for the three groups in Table 6. The table shows that, although Mexican-Hispanics are less likely to enter selfemployment than whites, they are 1.5 percentage points more likely to enter a low barrier industry than whites. Both Hispanic groups are however less likely to enter business ownership in a high barrier industry. The table suggests that about 2/3 of MexicanHispanic business start-ups are in low barrier industry while only about $1 / 3$ of white business entries are in these industries. The table also shows that Hispanics are more likely to exit business ownership over the sample period than whites. Interestingly, although white owned businesses in the higher barrier industries are more likely to survive than low barrier industry, the reverse holds for Hispanics. This suggests that the differences in self-employment exit rates are not entirely due to differences in industry distribution across groups, in which Hispanics are simply "pushed” into low barrier industries. Given that the Hispanic-white exit rate gaps are greater the greater the barrier to enter the industry, it may not be surprising that potential Hispanic entrepreneurs are more likely to start businesses in low barrier industries, relative to whites. We discuss this further and look at the role of observables in explaining these differences in the results section. 


\section{Empirical Results}

We begin the empirical analysis by estimating logit models of self-employment entry and exit, including two dummy variables capturing differences in the conditional transition probabilities between Mexican-Hispanics and whites, and Other-Hispanics and whites. All models include controls for year effects.

\section{Self-employment Entry}

Table 7 shows the marginal effects from estimated logit models of the probability of entering self-employment. As seen in Model 1, the unadjusted entry rate differences between the Mexican-Hispanics and whites is quite small, about $0.3 \%$, while Hispanics not of Mexican descent are approximately $0.8 \%$ more likely to enter self-employment compared to whites. When controls for educational attainment are added, shown as Model 2, Mexican-Hispanics are more likely to enter self-employment than whites, although the difference is insignificant in both models, as it is when additional controls are added, as seen in Models 3-5. This also holds true for the entry rate difference between Other-Hispanics and whites.

Also of interest are the effects of the determinants on the entry probability. Models 2-5 point to a large college graduation effect on the probability of a business start-up. The estimates indicate that a college graduate is about 1.5 percentage point more likely to become a business owner compared to both high school dropouts and graduates. The results in Model 4 shows that the longer an individual has held his job, the lower the probability is that he will become a business owner. Model 4 also shows a strong positive effect of experiencing unemployment in the previous year on the probability of becoming 
a business owner. Given that the specification also controls for job tenure, the estimated effect captures the effect of a change in labor force status and may be viewed as a “timing” effect. Holding everything else constant, an individual is more likely to enter self-employment after having left employment to become unemployed, compared to not leaving employment.

Wealth and asset income also have a positive impact on the self-employment entry probability, as shown in Model 5. An increase of $\$ 100,000$ in household wealth, roughly the difference in mean household wealth between Mexican-Hispanics and whites, increases the entry probability only by 0.01 percentage points. An increase in annual asset income of $\$ 1,000$ increases the probability an individual will enter selfemployment by 0.07 percentage points. These appear to be rather small effects, although statistically significant, but they also represent about $1 / 4$ of the entry rate gap between Mexican-Hispanics and whites.

\section{Self-employment Exit}

Table 8 shows the marginal effects based on the estimated logit models of yearover-year self-employment exits. Unlike entry rates, there are large differences in business failure, or exit, rates across the three groups. The unadjusted differences between whites and Hispanics are close to 10 percentage points higher for MexicanHispanics and about 6.5 percentage points for Other-Hispanics. As the results from Model 2 indicate, when education controls are added, the gap for both Hispanic groups drops by about 15\%. Model 3 shows that differences in demographic composition (i.e. age, family structure, nativity and geographic location) appear to be contributors to 
higher business ownership exit rates among Hispanics. According to Model 3 estimates, Mexican-Hispanics are about 6.5 percentage points more likely to exit self-employment, compared to an observably similar white male.

Not surprisingly, how long a business owner has been in operation has an impact on the probability of exiting self-employment. The results in Model 4 indicates that an entrepreneur who has been in business for 10 years is about 5 percentage points less likely to give up his business, compared to after the first year of ownership. Differences in business ownership tenure across groups further explain the higher Hispanic selfemployment exit rates, compared to whites. When these factors are controlled for the gap drops to about 5 percentage points for Mexican-Hispanics and to about 2.3 percentage points for Other-Hispanics. Lastly, Model 5 shows that higher wealth levels and asset income are associated with slightly lower exit rates and a further small decrease in the exit rate gaps between whites and Hispanics. Overall, the results in Table 8 suggest that roughly half the exit rate gap between Mexican-Hispanics and whites is due to differences in observable characteristics, while almost $2 / 3$ of the higher self-employment exit rate among Other-Hispanics, relative to whites, is due to differences in these factors. However, the shares of the exit rate gaps that can be attributed to observable characteristics are arguably somewhat pointless since Models 4 and 5 include controls for business survival, i.e. years of owning the business. A more conservative, and maybe more appropriate, share of the exit rate gaps due to differences in observable characteristics, based on Model 3, are 1/3 and 1/2 respectively for the two Hispanic groups. 
The Impact of Differences in Exit and Entry Rates on Self-employment Rates

In this section we investigate the role of differences in entry and exit rates on the Hispanic-white self-employment gap. We utilize the assumption that the transition rates are in steady-state and hence the self-employment rate can be expressed as the Entry Rate / (Entry Rate + Exit Rate). Another goal is to asses how differences in observable characteristics not only impact the transition rates but how they affect business ownership rates.

One way to illustrate how small differences in entry rates have a meaningful impact on self-employment rates, and differences between groups, is to demonstrate what the self-employment gap would be if Mexican-Hispanics were as likely to enter selfemployment as whites, i.e. an increase in the Mexican-Hispanic self-employment entry rate by only $0.3 \%$. In this hypothetical example, the Mexican-Hispanic self-employment rate would increase by slightly more than one percentage point and hence reduce the selfemployment rate gap by that amount.

The decomposition results shown in Table A3 show that the contribution from differences in educational attainment between Mexican-Hispanics and whites to the entry rate gap is about $0.32 \%$. This implies that if Mexican-Hispanics had the same educational attainment distribution as whites, the self-employment gap would be decreased by roughly 1.3 percentage points. The contribution from differences in household wealth and asset income between these two groups is slightly less that $0.1 \%$, which would decrease the self-employment gap by about another 0.4 percentage points.

The largest differences between Hispanics and whites are not in the entry rates but in business ownership exit rates. If we perform the same hypothetical example as above, 
but instead of assuming white entry rates for Hispanics we assume the white exit rate, the implied self-employment rate gap between Mexican-Hispanics and whites drop to slightly less than two percentage points, while the gap is turned into a "surplus" for Other-Hispanics. If we turn to the role of differences in observable characteristics and use the decomposition results in Table A4, we see that about $40 \%$ of the observed exit rate gap is due to differences in observable characteristics between Mexican-Hispanics and whites. The respective proportion of the exit rate gap for Other-Hispanics is slightly higher at $42 \%$. If we use these estimates and derive "implied" self-employment rate gaps, we see that Mexican-Hispanic self-employment rates would be about 2 percentage point higher while business ownership rates among Other-Hispanics would increase by approximately 2.5 percentage points. Note however that the latter calculations are based on estimates which include controls for years of business ownership, which accounts for almost half the gaps attributable to our observable controls.

Although these "rough" calculations show that differences in observable characteristics explain part of the observed self-employment gap, they also illustrate that large, unexplained, differences remain between Hispanics and whites. The next section attempts to address the role of industries in further explaining entrepreneurship differences between Hispanics and whites.

\section{The Role of Industries and Potential Entry Barriers}

To address the role of industries in the business start-up decision, we estimate multinomial logit model with four choice categories; no entry, entry into a low barrier industry, entry into a medium barrier industry or entry into a high barrier industry. We 
present the estimated gaps based on different specifications in Table $9 .{ }^{4}$ The table shows that without any controls for observable factors, both Hispanics groups are more likely to enter business ownership in a low barrier industry than whites, by about 1.5 and 2 percentage points respectively. However, Mexican Hispanics are about 1.5 percentage points less likely to enter either a medium or high barrier industry compared to whites, while there are no differences in the probability to start a business in the medium barrier industry for Other-Hispanics. They latter group is however close to one percentage point less likely to enter a high barrier industry than whites. Although the unadjusted differences are quite informative, in that they point out that the type of business start-ups for Hispanics and whites are very different, they may be due to differences in education and wealth.

The remaining columns in Table 9 attempt to address the specific roles of education and financial capital in explaining the observed differences across groups. In the specification with controls only for schooling levels, there are no differences between Hispanics and whites in entry rates to the low barrier industry category. This is due to the negative relationship between business start-up in the low barrier category and higher levels of educational attainment. The results also indicate that the lower entry rates into medium and high barrier industries is largely due to the lower schooling levels of Hispanics. The white-Mexican Hispanic business start-up gap drops by about $50 \%$ and 75\% respectively for these industry categories. Although our estimates for the entry rate gaps into these industry categories appear to be affected by differences in wealth, these effects are not as strong as the impact of education. In fact, adding controls for all

\footnotetext{
${ }^{4}$ Multinomial logit parameter vectors and standard errors are not shown but are available on request from the authors.
} 
observable characteristics does not change the estimated gaps by much compared to the specification with only schooling level controls. Overall, these results suggest that Hispanics entrepreneurs are quite likely to start their own business but given their relatively low levels of education, these start-ups are to a large extent restricted to low barrier industries, such as businesses in gardening/landscaping and construction.

The relatively higher Hispanic entry rates into firms in the low barrier industry category may also partly explain the higher Hispanic self-employment exit rates discussed above. Table 10 shows the estimated Hispanic-white exit rates gap by industry categories. As Table 6 indicates, overall, the exit rates are monotonically decreasing as the barriers increase. However, the reverse is true for Hispanics. It should be pointed out that the Hispanic-white industry exit rates gaps are not very precisely estimated due to the relatively few observations in each of these cells. Nonetheless, the results in Table 10 indicate higher self-employment exit rates for Hispanics in all three industry categories and that the differences are particularly large for entrepreneurs operating businesses in the medium and high barrier industries.

Again, we attempt to address the role of education and wealth in explaining these differences. Unlike the entry rate results, the Hispanic-white exit rate gap appears to somewhat more of an issue of differences in wealth than schooling levels. For example, the observed exit rate gaps in the medium barrier industry are about 12 and 9 percent points respectively for Mexican and Other-Hispanics. The estimated gaps with only schooling level controls drop to roughly 7 and 4 percentage points while the gap decrease to approximately 4 and 1 percentage points with only wealth controls. This suggests the possibility that once a Hispanic entrepreneur has started a business, he faces additional 
capital constraints, compared to whites, that decreases the survival probability, even within industry group. Also noteworthy, the estimated Mexican Hispanic-white exit rate gap for firms in the low barrier industry group turns to a "deficit” when we control for all observable characteristics, suggesting that the observed higher exit rates are entirely due to differences in observable characteristics. ${ }^{5}$ Furthermore, the results also suggest that the higher observed exit rates for non-Mexican Hispanics in all industry groups are due to differences in observable characteristics. Lastly, the lower business survival rates among Mexican-Hispanics in the higher barrier industries also provides an additional potential explanation for the concentration of Mexican-Hispanic business start-ups in the low barrier industry group, since the lower survival rates in the high barrier industry make these ventures more risky even for an observationally similar Hispanic entrepreneur, compared to a non-Hispanic white entrepreneur.

\section{Summary and Conclusions}

This paper contributes to the minority entrepreneurship research by analyzing self-employment among Hispanics, an important and growing minority group which has been relatively overlooked in the entrepreneurship literature. Our data reveals that Hispanic males are substantially less likely to be business owners, relative to whites. The self-employment gap is particularly large for Mexican-Hispanics, whose selfemployment rates are about half the self-employment rates among non-Hispanic whites. We investigate the causes of the Hispanic-white difference in business ownership rates by analyzing self-employment entry and exit rates.

\footnotetext{
${ }^{5}$ Importantly, this holds true whether or not we include controls for years of business ownership.
} 
We observe relatively small differences in self-employment entry rates across groups, with Other-Hispanics displaying the highest entry rates. We argue that this should not be interpreted as Hispanics do not face additional barriers to enter self-employment. We observe differences across groups in forms of businesses owned, i.e. incorporated or unincorporated, and industry composition. Although these differences are partially due to differences in factors such as educational attainment, they are also consistent with minority business start-up credit constraints which lead to less well funded small business and/or selection into less capital intensive industries. Also, we show that relatively small differences in entry rates have a meaningful impact on the Hispanic self-employment gap. The data also reveal large differences in business survival, or exit, rates, and show that Hispanics are substantially more likely to exit self-employment than whites.

Our estimates indicate that education plays an important role in the business startup decision and that after controlling for differences in educational attainment across groups, Hispanics are as likely to enter self-employment as whites. Household wealth and asset income also affects the entry decision, as well as differences in entry probabilities across groups. Our results indicate that between 20 and 40 percent of the Hispanic-white exit rate gap is due to differences in our observable controls. Although our results point to education and financial capital as factors partly explaining the observed low Hispanic self-employment rates, it also indicates that a substantial part of the gap remains unexplained.

We discuss and analyze the role of industries in further explaining differences in entrepreneurship between Hispanics and whites. We categorize firms into three industry groups based on human and financial capital requirements to enter the industry; low, 
medium and high barriers to enter industries. This reveals that Hispanics are more likely than whites to become business owners in the low barrier industry group. The observed lower self-employment entry rates among Hispanics are due to lower entry rates into the relatively higher barrier industries. Our analysis indicates that this is primarily due to lower educational attainment levels, although difference in financial wealth appears to contribute to some extent. Hispanic entrepreneurs in all three industry groups are more likely to leave self-employment than whites. Furthermore, the Hispanic-white exit rate gap is greater the greater the barrier to enter the industry is. We find that the observed higher business ownership exit rates among Mexican-Hispanics, compared to whites, in the low barrier industry group is explained by differences in observable characteristics. Moreover, our results suggest a greater role in explaining differences in exit rates across groups to differences in wealth rather than differences in education, although the latter also contributes to the gap. The role of wealth differences may point to relatively less well financed Hispanic businesses as an explanation for the higher failure rates and may be due to stronger capital constraints faced by Hispanics. Also, the results provide an additional rationale for the concentration of Mexican-Hispanic business start-ups in the low barrier industry group. The relatively lower Mexican-Hispanic survival rates in the high barrier industry make these ventures more risky for Mexican-Hispanics than whites, and arguably less attractive.

Although our findings shed light on the white-Hispanic self-employment gap, it also points to the need for further research to more accurately assess, particularly, the higher business failure rates among Hispanics. Our relatively small sample size makes the industry specific exit rate estimates rather imprecise and should be interpreted with 
the appropriate discretion. Nonetheless they are suggestive of some potential explanations.

Lastly, our results quite strongly indicate the importance of education in explaining differences in business ownership between Hispanics and whites, not only as a determinant of the self-employment gap, but also in its effects on what type of business start-ups entrepreneurs are likely to pursue. Furthermore, since business survival rates vary across industries, education also has an indirect impact on self-employment exit rates. Overall, this suggests yet another area in which education is a key determinant in economic success. 


\section{Appendix}

\section{Decomposition of Transition Rate Gaps}

To assess the specific role of differences in observable characteristics across groups in explaining Hispanic-white entry and exit rates gaps, we utilize a non-linear Blinder-Oaxaca decomposition as proposed by Fairlie (1999). The decompositions are based on the estimated logit parameter vectors from a specification similar to Model 5 shown in Tables 7 and 8, but exclude the Hispanic indicator variables. The decomposition results are presented in Tables A3 and A4.

Since the decomposition is based on logit results from separate regressions for the three groups, it has the advantage that it relaxes the assumption that observables have the same impact on transition probabilities across groups. Furthermore, this approach has the advantage, compared to the technique utilized in Tables 7 and 8, that the order in which controls are added is irrelevant. That is, for example, in Tables 7 and 8 we add education controls first and assign the drop in the Hispanic coefficients to differences in educational attainment alone, ignoring the likely possibility that education is positively correlated with wealth, for example. This may or may not be an important issue. A comparison of the decomposition results to the discussion in Section 6 suggests no real changes in conclusions based on the two approaches to analyze group differences. 


\section{References}

Bates, Timothy. 1989. "The Changing Nature of Minority Business: A Comparative Analysis of Asian, Nonminority, and Black-Owned Businesses" The Review of Black Political Economy, 18, Fall: 25-42.

Bates, Timothy. 1990. "Entrepreneur Human Capital Inputs and Small Business Longevity," Review of Economics and Statistics 72 (4): 551-59.

Bates, Timothy. 1990. "Self-Employment Trends Among Mexican Americans”, Working Paper, U.S. Census Economic Studies.

Bates, Timothy. 1995. “Self-Employment Entry across Groups” Journal of Business Venturing, 10: 143-156

Bates, Timothy. 1997. Race, Self-Employment \& Upward Mobility: An Illusive American Dream, Washington, D.C.: Woodrow Wilson Center Press and Baltimore: John Hopkins University Press.

Betts, Julian R. and Magnus Lofstrom. 2000. "The Educational Attainment of Immigrants: Trends and Implications,” in George J. Borjas ed. Issues in the Economics of Immigration, University of Chicago Press, for National Bureau of Economic Research, pp. 51-115.

Blanchflower, David G. 2004. “Self-Employment: More May Not Be Better”, NBER Working paper No. 10286.

Blanchflower, David G., P. Levine and D. Zimmerman. 2003. "Discrimination in the Small Business Credit Market", Review of Economics and Statistics, November, 85(4): 930-943

Blanchflower, David G. and Andrew J. Oswald. 1998. "What Makes an Entrepreneur?” Journal of Labor Economics,16, 26-60.

Cummings, Scott. 1980. Self-Help in Urban America: Patterns of Minority Business Enterprise, Kenikart Press, New York.

Dunn, T. and D. Holtz-Eakin. 2000. "Financial Capital, Human Capital, and the Transition to Self-Employment: Evidence from Intergenerational Links.” Journal of Labor Economics,18, 282-305.

Evans, David S. and Boyan Jovanovic. 1989. "An Estimated Model of Entrepreneurial Choice under Liquidity Constraints.” Journal of Political Economy, 97, 808-827.

Evans, David S. and Linda S. Leighton. 1989. "Some Empirical Aspects of Entrepreneurship”. American Economic Review, 79, 519-35. 
Fairlie, Robert W. and Christopher Woodruff. 2005. "Mexican-American Entrepreneurship" Paper presented at the $10^{\text {th }}$ Annual Meeting of the Society of Labor Economists, San Francisco, June 2005.

Fairlie, Robert W. 1999. "The Absence of the African-American Owned Business: An Analysis of the Dynamics of Self-Employment." Journal of Labor Economics, 17(1): 80-108.

Fairlie, Robert W. and Meyer, Bruce D. 1996. "Ethnic and Racial Self-Employment Differences and Possible Explanations.” Journal of Human Resources 31:757-93.

Glazer, Mathan and Daniel P. Moynihan. 1970. Beyond the Melting Pot: the Negroes, Puerto Ricans, Jews, Italians and Irish of New York City, MIT Press, Cambridge.

Holtz-Eakin, Douglas, David Joulfaian and Harvey S. Rosen. 1994a. "Sticking it Out: Entrepreneurial Survival and Liquidity Constraints.” Journal of Political Economy, 102, 53-75.

Holtz-Eakin, Douglas, David Joulfaian and Harvey S. Rosen. 1994b. "Entrepreneurial Decisions and Liquidity Constraints” Rand Journal of Economics, 25, 334-47.

Hurst, Erik, and Annamaria Lusardi. 2004. "Liquidity Constraints, Household Wealth, and Entrepreneurship," Journal of Political Economy, 112(2): 319-347.

Kihlstrom, Richard E. and Jean-Jacques Laffont. 1979. “A General Equilibrium Entrepreneurial Theory of Firm Formation Based on Risk Aversion” Journal of Political Economy, 87:4, 719-748.

Lindh, Thomas and Henry Ohlsson. 1996. "Self-Employment and Windfall Gains. Evidence from the Swedish Lottery”. The Economic Journal, 106, 1515-1526.

Lofstrom, Magnus. 2002. "Labor Market Assimilation and the Self-Employment Decision of Immigrant Entrepreneurs,” Journal of Population Economics, 15(1): 83-114.

Taniguchi, Hiromi. 2002. “Determinants of Women’s Entry into Self-Employment” Social Science Quarterly, 3: 875-93. 
Table 1.

Sample Means by Ethnicity/Race

\begin{tabular}{lccc}
\hline & \multicolumn{2}{c}{ Hispanic } & $\begin{array}{c}\text { White } \\
\text { (Non-Hispanic) }\end{array}$ \\
\hline High School Dropout & 0.42 & 0.26 & 0.09 \\
High School Graduate & 0.30 & 0.27 & 0.31 \\
Some College & 0.23 & 0.30 & 0.30 \\
College Graduate & 0.06 & 0.17 & 0.30 \\
Age & 37.21 & 39.86 & 41.61 \\
Married & 0.67 & 0.63 & 0.68 \\
Number of Children & 1.52 & 0.99 & 0.80 \\
Number of Persons in Household & 4.33 & 3.54 & 3.03 \\
Urban Resident & 0.88 & 0.95 & 0.77 \\
Immigrant & 0.48 & 0.52 & 0.03 \\
Years Since Immigration & 7.46 & 7.53 & 0.57 \\
Annual Earnings & 20,016 & 23,883 & 35,568 \\
Hours Work/Week & 36.61 & 36.62 & 39.50 \\
Self-employed & 0.085 & 0.117 & 0.161 \\
Wage/Salary & 0.759 & 0.720 & 0.703 \\
Unemployed & 0.034 & 0.036 & 0.016 \\
Not in Labor Force & 0.122 & 0.127 & 0.121 \\
Household Wealth & 49,733 & 65,122 & 165,122 \\
Annual Household Asset Income & 118 & 234 & 784 \\
Sample Size & & & \\
Number of Individuals & 10,720 & 5,138 & 124,876 \\
\hline
\end{tabular}


Table 2.

Sample Statistics by Ethnicity/Race and Self-Employment (conditional on employment)

\begin{tabular}{|c|c|c|c|c|c|c|}
\hline & \multicolumn{4}{|c|}{ Hispanic } & \multirow{2}{*}{\multicolumn{2}{|c|}{$\begin{array}{c}\text { White } \\
\text { (Non-Hispanic) }\end{array}$}} \\
\hline & \multicolumn{2}{|c|}{ Mexican } & \multicolumn{2}{|c|}{ Other } & & \\
\hline & Wage/Salary & Self-Employed & Wage/Salary & Self-Employed & Wage/Salary & Self-Employed \\
\hline High School Dropout & 0.40 & 0.46 & 0.23 & 0.21 & 0.06 & 0.07 \\
\hline High School Graduate & 0.30 & 0.23 & 0.28 & 0.29 & 0.32 & 0.28 \\
\hline Some College & 0.24 & 0.22 & 0.31 & 0.28 & 0.31 & 0.27 \\
\hline College Graduate & 0.06 & 0.09 & 0.19 & 0.22 & 0.31 & 0.38 \\
\hline Age & 36.07 & 42.28 & 39.44 & 40.85 & 40.10 & 44.45 \\
\hline Married & 0.69 & 0.79 & 0.66 & 0.74 & 0.69 & 0.76 \\
\hline Number of Children & 1.59 & 1.60 & 1.01 & 1.22 & 0.85 & 0.90 \\
\hline Number of Persons in Household & 4.37 & 4.30 & 3.56 & 3.62 & 3.08 & 3.11 \\
\hline Urban Resident & 0.90 & 0.82 & 0.96 & 0.94 & 0.78 & 0.74 \\
\hline Immigrant & 0.49 & 0.50 & 0.53 & 0.67 & 0.03 & 0.03 \\
\hline Years Since Immigration & 7.41 & 8.31 & 7.21 & 11.37 & 0.53 & 0.77 \\
\hline \multicolumn{7}{|l|}{ Total Annual Earnings } \\
\hline Mean & 23,040 & 22,246 & 27,700 & 27,865 & 39,023 & 46,866 \\
\hline Median & 19,610 & 16,640 & 22,068 & 17,600 & 32,036 & 29,889 \\
\hline Hours Work/Week & 41.32 & 46.24 & 41.54 & 47.89 & 43.44 & 50.49 \\
\hline Job Tenure & 6.42 & N/A & 6.68 & N/A & 8.79 & N/A \\
\hline Business Tenure & N/A & 6.81 & N/A & 6.22 & N/A & 9.63 \\
\hline \multicolumn{7}{|l|}{ Household Wealth } \\
\hline Mean & 45,828 & 81,465 & 56,659 & 138,041 & 135,693 & 304,735 \\
\hline Median & 15,050 & 36,537 & 15,325 & 43,640 & 57,141 & 135,096 \\
\hline Annual Household Asset Income & 125 & 151 & 217 & 585 & 632 & 1,452 \\
\hline Sample Size & 8,133 & 913 & 3,698 & 603 & 87,775 & 20,102 \\
\hline
\end{tabular}


Table 3.

Self-Employment Ratios and Transitions (in \%) by Race/Ethnicity.

\begin{tabular}{lcccccc} 
& \multicolumn{2}{c}{ Mexican Hispanics } & \multicolumn{2}{c}{ Other Hispanics } & \multicolumn{2}{c}{ White Non-Hispanics } \\
& Percent & $\mathrm{N}$ & Percent & $\mathrm{N}$ & Percent & $\mathrm{N}$ \\
\hline Self-Employment Ratio & 8.52 & 10,720 & 11.74 & 5,138 & 16.10 & 124,876 \\
Transitions & & & & & & \\
Entry & 2.36 & 9,618 & 3.40 & 4,472 & 2.65 & 103,204 \\
$\quad$ Entry from Wage/Salary & 2.09 & 8,328 & 3.14 & 3,760 & 2.59 & 89,557 \\
$\quad$ Entry from Unemployment & 6.01 & 316 & 10.23 & 176 & 9.41 & 1,520 \\
$\quad$ Entry from NILF & 5.16 & 1,008 & 5.62 & 569 & 4.73 & 12,760 \\
& & & & & & \\
Exit & 20.46 & 831 & 18.63 & 542 & 11.35 & 19,188 \\
$\quad$ Exit to Wage/Salary & 15.52 & & 16.97 & & 9.05 & \\
$\quad$ Exit to Unemployment & 1.44 & & 0.18 & & 0.32 & \\
$\quad$ Exit to NILF & 3.49 & & 1.48 & & & 1.98 \\
\hline
\end{tabular}

Table 4.

Business Ownership Characteristics, Sample Means, by Race/Ethnicity.

\begin{tabular}{lccc}
\hline & \multicolumn{2}{c}{ Hispanic } & White \\
& Mexican & Other & (Non-Hispanic) \\
\hline \multicolumn{1}{c}{ Business Type (\%) } & & & \\
Incorporated & 7.4 & 27.9 & 27.4 \\
Unincorporated & 69.1 & 44.8 & 49.2 \\
Unincorporated w/ Partner & 10.3 & 14.3 & 11.1 \\
Household Business Partner & 6.2 & 14.8 & 11.6 \\
& & & \\
Business Tenure & 6.81 & 6.22 & 9.63 \\
Business Equity & 25,037 & 54,722 & 89,537 \\
\hline
\end{tabular}


Table 5.

Business Ownership - Industry Characteristics and Distribution, by Race/Ethnicity.

\begin{tabular}{lccccc}
\hline & Industry Characteristics & \multicolumn{2}{c}{ Hispanic } & White \\
& Sample & Mean & Mexican & Other & (Non-Hispanic) \\
\hline & Years of & Business & & & \\
& Schooling & Equity $(\$)$ & Percent in Industry & \\
Agriculture/Forestry/Fisheries & 13.0 & 176,169 & 5.5 & 5.3 & 9.4 \\
Construction & 12.4 & 64,595 & 33.1 & 19.8 & 19.9 \\
Manufacturing & 13.8 & 106,813 & 3.9 & 3.3 & 5.6 \\
Transportation/Communications & 12.3 & 59,313 & 6.6 & 5.0 & 4.6 \\
Wholesale Trade & 14.0 & 139,648 & 1.1 & 4.2 & 5.4 \\
Retail trade & 13.3 & 71,833 & 13.9 & 14.2 & 10.0 \\
Finance/Insurance/Real estate & 15.0 & 112,720 & 3.0 & 1.9 & 5.9 \\
Business Services & 14.5 & 63,265 & 3.0 & 13.0 & 8.5 \\
Personal Services & 13.9 & 57,700 & 3.8 & 3.3 & 3.1 \\
Entertainment/Recreation Services & 14.6 & 20,587 & 2.0 & 2.1 & 4.2 \\
Professional/Related Services & 17.7 & 98,527 & 3.9 & 8.2 & 16.6 \\
Gardening/Landscaping & 11.5 & 63,168 & 6.8 & 3.9 & 2.0 \\
Repair Services & 11.7 & 26,275 & 13.5 & 15.7 & 4.4 \\
Other & 13.7 & 102,521 & 0.0 & 0.2 & 0.3 \\
\hline
\end{tabular}

Table 6.

Transition Probabilities by Industry Group, Full Sample Period, by Race/Ethnicity.

\begin{tabular}{|c|c|c|c|c|c|c|}
\hline & \multicolumn{2}{|c|}{ Hispanic } & \multirow[t]{2}{*}{ White } & \multicolumn{2}{|c|}{ Hispanic } & \multirow[t]{2}{*}{ White } \\
\hline & Mexican & Other & & Mexican & Other & \\
\hline & \multicolumn{6}{|c|}{ Sample Period Transition Probabilities } \\
\hline & \multicolumn{3}{|c|}{ Entry } & \multicolumn{3}{|c|}{ Exit } \\
\hline No Transition & 93.7 & 90.8 & 91.9 & 58.1 & 63.8 & 68.7 \\
\hline \multicolumn{7}{|l|}{ Transitions } \\
\hline Entry/Exit Low Barrier Industryi) & 4.4 & 4.9 & 2.9 & 39.9 & 32.3 & 33.0 \\
\hline Entry/Exit Medium Barrier Industry & 1.8 & 3.4 & 3.4 & 44.1 & 40.7 & 31.6 \\
\hline Entry/Exit High Barrier Industry $\left.{ }^{\mathrm{iii}}\right)$ & 0.2 & 0.9 & 1.9 & 50.5 & 43.8 & 27.8 \\
\hline Number of Individuals & 1,436 & 710 & 14,946 & 169 & 108 & 3,205 \\
\hline $\begin{array}{l}\text { i) Gardening/Landscaping, Construction, } \\
\text { ii) Agriculture, Manufacturing, Transporta } \\
\text { services, Entertainment/recreation serv }\end{array}$ & $\begin{array}{l}\text { il trade or } \\
\text { communic }\end{array}$ & $\begin{array}{l}\text { epair ser } \\
\text { tions, W }\end{array}$ & $\begin{array}{l}\text { ices } \\
\text { olesale tra }\end{array}$ & siness se & ces, Pe & \\
\hline
\end{tabular}


Table 7.

Marginal Effects, Logit Models of Probability of Entry into Self-Employment.

\begin{tabular}{|c|c|c|c|c|c|}
\hline Variable & Model 1 & Model 2 & Model 3 & Model 4 & Model 5 \\
\hline Mexican-Hispanic & $\begin{array}{l}-0.003 \\
(1.01)\end{array}$ & $\begin{array}{c}0.0003 \\
(0.11)\end{array}$ & $\begin{array}{l}-0.004 \\
(1.49)\end{array}$ & $\begin{array}{l}-0.004 \\
(1.52)\end{array}$ & $\begin{array}{l}-0.004 \\
(1.49)\end{array}$ \\
\hline Other-Hispanic & $\begin{array}{l}0.008 \\
(1.54)\end{array}$ & $\begin{array}{l}0.009 \\
(1.79)\end{array}$ & $\begin{array}{l}0.003 \\
(0.78)\end{array}$ & $\begin{array}{l}0.003 \\
(0.64)\end{array}$ & $\begin{array}{l}0.003 \\
(0.69)\end{array}$ \\
\hline High School Graduate & & $\begin{array}{c}-0.0006 \\
(0.24)\end{array}$ & $\begin{array}{c}-0.0010 \\
(0.36)\end{array}$ & $\begin{array}{c}0.0022 \\
(0.84)\end{array}$ & $\begin{array}{l}0.002 \\
(0.79)\end{array}$ \\
\hline Some College & & $\begin{array}{l}0.003 \\
(1.02)\end{array}$ & $\begin{array}{l}0.002 \\
(0.71)\end{array}$ & $\begin{array}{l}0.005 \\
(1.96)\end{array}$ & $\begin{array}{l}0.005 \\
(1.86)\end{array}$ \\
\hline College Graduate & & $\begin{array}{l}0.013 \\
(3.92)\end{array}$ & $\begin{array}{l}0.011 \\
(3.30)\end{array}$ & $\begin{array}{l}0.016 \\
(4.61)\end{array}$ & $\begin{array}{l}0.014 \\
(4.32)\end{array}$ \\
\hline Age & & & $\begin{array}{l}0.002 \\
(3.75)\end{array}$ & $\begin{array}{l}0.003 \\
(6.97)\end{array}$ & $\begin{array}{l}0.003 \\
(7.07)\end{array}$ \\
\hline $\mathrm{Age}^{2} / 100$ & & & $\begin{array}{l}-0.002 \\
(4.26)\end{array}$ & $\begin{array}{l}-0.004 \\
(7.17)\end{array}$ & $\begin{array}{l}-0.004 \\
(7.34)\end{array}$ \\
\hline Married & & & $\begin{array}{l}0.002 \\
(0.96)\end{array}$ & $\begin{array}{l}0.005 \\
(2.93)\end{array}$ & $\begin{array}{l}0.005 \\
(2.93)\end{array}$ \\
\hline Number of Children & & & $\begin{array}{l}0.001 \\
(1.30)\end{array}$ & $\begin{array}{l}0.002 \\
(1.50)\end{array}$ & $\begin{array}{l}0.001 \\
(1.44)\end{array}$ \\
\hline Number of Persons in Hhold & & & $\begin{array}{l}-0.001 \\
(1.61)\end{array}$ & $\begin{array}{l}-0.001 \\
(1.88)\end{array}$ & $\begin{array}{l}-0.001 \\
(1.83)\end{array}$ \\
\hline Urban Resident & & & $\begin{array}{l}0.001 \\
(0.30)\end{array}$ & $\begin{array}{l}0.0003 \\
(0.22)\end{array}$ & $\begin{array}{l}0.0003 \\
(0.16)\end{array}$ \\
\hline Immigrant & & & $\begin{array}{l}0.004 \\
(0.48)\end{array}$ & $\begin{array}{l}0.002 \\
(0.29)\end{array}$ & $\begin{array}{l}0.002 \\
(0.29)\end{array}$ \\
\hline Years Since Immigration & & & $\begin{array}{l}0.001 \\
(0.85)\end{array}$ & $\begin{array}{l}0.001 \\
(0.95)\end{array}$ & $\begin{array}{l}0.001 \\
(0.98)\end{array}$ \\
\hline $\mathrm{YSM}^{2} / 100$ & & & $\begin{array}{l}-0.001 \\
(0.74)\end{array}$ & $\begin{array}{l}-0.001 \\
(0.74)\end{array}$ & $\begin{array}{l}-0.001 \\
(0.79)\end{array}$ \\
\hline Unemployed Previous Year & & & & $\begin{array}{l}0.016 \\
(5.91)\end{array}$ & $\begin{array}{l}0.016 \\
(5.97)\end{array}$ \\
\hline NILF Previous Year & & & & $\begin{array}{l}0.004 \\
(2.44)\end{array}$ & $\begin{array}{l}0.004 \\
(2.41)\end{array}$ \\
\hline Years at Job & & & & $\begin{array}{l}-0.001 \\
(5.48)\end{array}$ & $\begin{array}{l}-0.001 \\
(5.45)\end{array}$ \\
\hline Years at $\mathrm{Job}^{2} / 100$ & & & & $\begin{array}{l}0.003 \\
(2.95)\end{array}$ & $\begin{array}{l}0.003 \\
(2.92)\end{array}$ \\
\hline Household Wealth $_{\mathrm{t}-1}(\$ 100,000 \mathrm{~s})$ & & & & & $\begin{array}{c}0.0001 \\
(1.79)\end{array}$ \\
\hline Asset Income $_{\mathrm{t}-1}(\$ 10,000 \mathrm{~s})$ & & & & & $\begin{array}{c}0.007 \\
(4.060)\end{array}$ \\
\hline Number of Observations & & & 117,294 & & \\
\hline Log Likelihood & $-14,000$ & $-13,941$ & $-13,880$ & $-13,657$ & $-13,641$ \\
\hline
\end{tabular}

Note: Z-statistics, in parentheses, are based on standard errors obtained by relaxing the independence across individual observations assumption. Year effects are included in all model specifications. 
Table 8.

Marginal Effects, Logit Models of Probability of Exit Out of Self-Employment.

\begin{tabular}{|c|c|c|c|c|c|}
\hline Variable & Model 1 & Model 2 & Model 3 & Model 4 & Model 5 \\
\hline Mexican-Hispanic & $\begin{array}{l}0.099 \\
(3.79)\end{array}$ & $\begin{array}{l}0.085 \\
(3.19)\end{array}$ & $\begin{array}{l}0.066 \\
(2.52)\end{array}$ & $\begin{array}{l}0.049 \\
(2.28)\end{array}$ & $\begin{array}{l}0.046 \\
(2.17)\end{array}$ \\
\hline Other-Hispanic & $\begin{array}{l}0.063 \\
(2.29)\end{array}$ & $\begin{array}{l}0.056 \\
(2.09)\end{array}$ & $\begin{array}{l}0.028 \\
(1.04)\end{array}$ & $\begin{array}{l}0.023 \\
(0.95)\end{array}$ & $\begin{array}{l}0.022 \\
(0.90)\end{array}$ \\
\hline High School Graduate & & $\begin{array}{c}-0.0137 \\
(1.04)\end{array}$ & $\begin{array}{c}-0.0129 \\
(1.02)\end{array}$ & $\begin{array}{c}-0.0077 \\
(0.68)\end{array}$ & $\begin{array}{l}-0.006 \\
(0.54)\end{array}$ \\
\hline Some College & & $\begin{array}{c}0.0000 \\
(0.00)\end{array}$ & $\begin{array}{l}0.004 \\
(0.29)\end{array}$ & $\begin{array}{l}-0.001 \\
(0.08)\end{array}$ & $\begin{array}{l}0.001 \\
(0.12)\end{array}$ \\
\hline College Graduate & & $\begin{array}{l}-0.031 \\
(2.41)\end{array}$ & $\begin{array}{l}-0.022 \\
(1.70)\end{array}$ & $\begin{array}{l}-0.023 \\
(2.08)\end{array}$ & $\begin{array}{l}-0.017 \\
(1.49)\end{array}$ \\
\hline Age & & & $\begin{array}{l}-0.020 \\
(7.64)\end{array}$ & $\begin{array}{l}-0.015 \\
(6.04)\end{array}$ & $\begin{array}{l}-0.015 \\
(6.18)\end{array}$ \\
\hline $\mathrm{Age}^{2} / 100$ & & & $\begin{array}{l}0.020 \\
(6.72)\end{array}$ & $\begin{array}{l}0.017 \\
(5.86)\end{array}$ & $\begin{array}{l}0.017 \\
(6.04)\end{array}$ \\
\hline Married & & & $\begin{array}{l}-0.037 \\
(3.53)\end{array}$ & $\begin{array}{l}-0.031 \\
(3.33)\end{array}$ & $\begin{array}{l}-0.030 \\
(3.27)\end{array}$ \\
\hline Number of Children & & & $\begin{array}{l}-0.023 \\
(4.71)\end{array}$ & $\begin{array}{l}-0.020 \\
(4.53)\end{array}$ & $\begin{array}{l}-0.020 \\
(4.55)\end{array}$ \\
\hline Number of Persons in Hhold & & & $\begin{array}{l}0.017 \\
(4.45)\end{array}$ & $\begin{array}{l}0.016 \\
(4.75)\end{array}$ & $\begin{array}{l}0.017 \\
(4.82)\end{array}$ \\
\hline Urban Resident & & & $\begin{array}{l}0.018 \\
(2.30)\end{array}$ & $\begin{array}{c}0.0118 \\
(1.63)\end{array}$ & $\begin{array}{c}0.0120 \\
(1.66)\end{array}$ \\
\hline Immigrant & & & $\begin{array}{l}0.036 \\
(0.74)\end{array}$ & $\begin{array}{l}-0.005 \\
(0.13)\end{array}$ & $\begin{array}{l}-0.004 \\
(0.12)\end{array}$ \\
\hline Years Since Immigration & & & $\begin{array}{l}-0.003 \\
(0.69)\end{array}$ & $\begin{array}{l}-0.001 \\
(0.16)\end{array}$ & $\begin{array}{l}-0.001 \\
(0.16)\end{array}$ \\
\hline $\mathrm{YSM}^{2} / 100$ & & & $\begin{array}{l}0.004 \\
(0.52)\end{array}$ & $\begin{array}{l}0.001 \\
(0.14)\end{array}$ & $\begin{array}{l}0.001 \\
(0.16)\end{array}$ \\
\hline Years Owning Business & & & & $\begin{array}{l}-0.007 \\
(6.14)\end{array}$ & $\begin{array}{l}-0.007 \\
(5.98)\end{array}$ \\
\hline Years Owning Business ${ }^{2} / 100$ & & & & $\begin{array}{l}0.012 \\
(3.89)\end{array}$ & $\begin{array}{l}0.012 \\
(3.82)\end{array}$ \\
\hline In Sample Business Entry & & & & $\begin{array}{c}0.101 \\
(10.00)\end{array}$ & $\begin{array}{l}0.100 \\
(9.93)\end{array}$ \\
\hline Household Wealth $_{\mathrm{t}-1}(\$ 100,000 \mathrm{~s})$ & & & & & $\begin{array}{l}-0.001 \\
(1.19)\end{array}$ \\
\hline Asset Income $_{\mathrm{t}-1}(\$ 10,000 \mathrm{~s})$ & & & & & $\begin{array}{c}-0.0151 \\
(1.53)\end{array}$ \\
\hline Number of Observations & & & 20,561 & & \\
\hline Log Likelihood & $-7,475$ & $-7,457$ & $-7,237$ & $-6,902$ & $-6,893$ \\
\hline
\end{tabular}


Table 9.

Entry Rate Gap by Industry Group, Full Sample Period, by Race/Ethnicity.

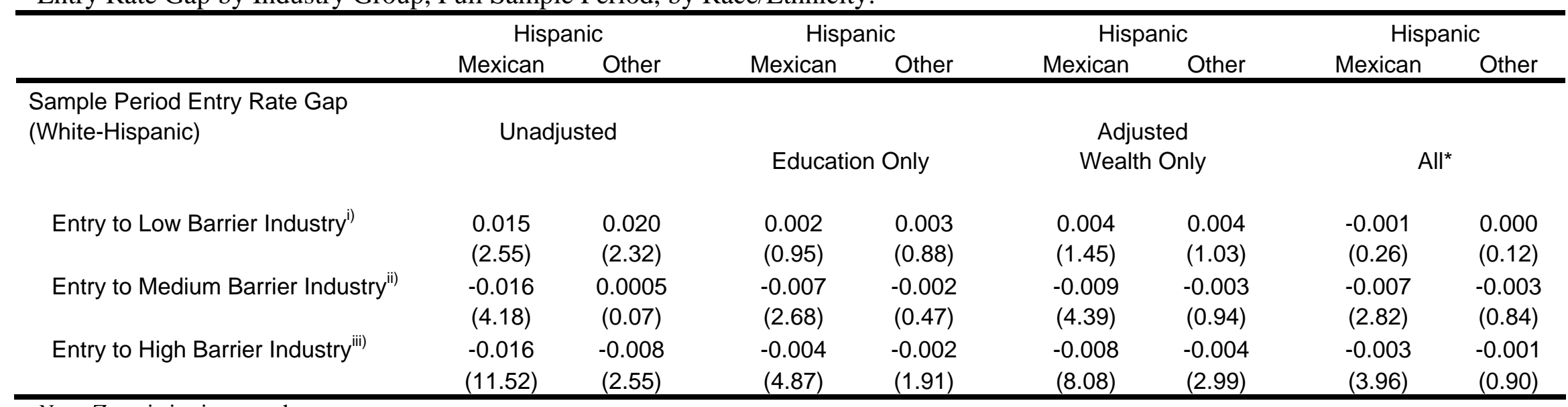

Note: Z-statistics in parentheses.

i) Gardening/Landscaping, Construction, Retail trade or Repair services

ii) Agriculture, Manufacturing, Transportation/communications, Wholesale trade, Business services, Personal services, Entertainment/recreation services

iii) Finance/Insurance/Real estate, Professional/Related services or Other

*) Estimated adjusted gap is based on a Multinomial Logit Model with covariates as in Model 5, Table 9. 
Table 10.

Exit Rate Gap by Industry Group, Full Sample Period, by Race/Ethnicity.

\begin{tabular}{|c|c|c|c|c|c|c|c|c|}
\hline & \multicolumn{2}{|c|}{ Hispanic } & \multicolumn{2}{|c|}{ Hispanic } & \multicolumn{2}{|c|}{ Hispanic } & \multicolumn{2}{|c|}{ Hispanic } \\
\hline & Mexican & Other & Mexican & Other & Mexican & Other & Mexican & Other \\
\hline $\begin{array}{l}\text { Sample Period Exit Rate Gap } \\
\text { (Hispanic-White) }\end{array}$ & \multicolumn{2}{|c|}{ Unadjusted } & \multicolumn{6}{|c|}{$\begin{array}{l}\text { Adjusted } \\
\text { Wealth Only }\end{array}$} \\
\hline Exit from Low Barrier Industryi) & $\begin{array}{l}0.069 \\
(1.32)\end{array}$ & $\begin{array}{r}-0.007 \\
(0.11)\end{array}$ & $\begin{array}{l}0.047 \\
(0.76)\end{array}$ & $\begin{array}{l}-0.061 \\
(0.91)\end{array}$ & $\begin{array}{l}0.023 \\
(0.40)\end{array}$ & $\begin{array}{l}-0.091 \\
(1.50)\end{array}$ & $\begin{array}{l}-0.032 \\
(0.56)\end{array}$ & $\begin{array}{l}-0.126 \\
(2.21)\end{array}$ \\
\hline Exit from Medium Barrier Industry ${ }^{i i)}$ & $\begin{array}{l}0.125 \\
(1.65)\end{array}$ & $\begin{array}{l}0.092 \\
(1.07)\end{array}$ & $\begin{array}{l}0.069 \\
(0.77)\end{array}$ & $\begin{array}{l}0.044 \\
(0.42)\end{array}$ & $\begin{array}{l}0.038 \\
(0.45)\end{array}$ & $\begin{array}{l}0.010 \\
(0.10)\end{array}$ & $\begin{array}{l}0.013 \\
(0.17)\end{array}$ & $\begin{array}{l}-0.008 \\
(0.08)\end{array}$ \\
\hline Exit from High Barrier Industry ${ }^{\mathrm{iii}}$ & $\begin{array}{l}0.227 \\
(1.48) \\
\end{array}$ & $\begin{array}{l}0.160 \\
(0.97)\end{array}$ & $\begin{array}{l}0.157 \\
(1.15)\end{array}$ & $\begin{array}{l}0.050 \\
(0.29)\end{array}$ & $\begin{array}{l}0.168 \\
(1.26)\end{array}$ & $\begin{array}{l}0.015 \\
(0.10)\end{array}$ & $\begin{array}{l}0.143 \\
(1.21) \\
\end{array}$ & $\begin{array}{r}-0.020 \\
(0.12) \\
\end{array}$ \\
\hline
\end{tabular}

Note: Z-statistics in parentheses.

i) Gardening/Landscaping, Construction, Retail trade or Repair services

ii) Agriculture, Manufacturing, Transportation/communications, Wholesale trade, Business services, Personal services, Entertainment/recreation services

iii) Finance/Insurance/Real estate, Professional/Related services or Other

*) Estimated adjusted gap is based on separate logit models, by industry group, with covariates as in Model 5, Table 10. 


\section{Appendix Tables}

Table A1.

Summary Statistics, Sample Means, by Entry and No Entry.

\begin{tabular}{lcc}
\hline & \multicolumn{2}{c}{ Self-Employment Entry } \\
& No Entry & Entry \\
\hline High School Dropout & 0.12 & 0.11 \\
High School Graduate & 0.31 & 0.26 \\
Some College & 0.30 & 0.28 \\
College Graduate & 0.26 & 0.35 \\
Age & 40.76 & 39.78 \\
Married & 0.66 & 0.68 \\
Number of Children & 0.85 & 0.93 \\
Number of Persons in Household & 3.14 & 3.19 \\
Urban Resident & 0.79 & 0.80 \\
Immigrant & 0.08 & 0.11 \\
Years Since Immigration & 1.33 & 1.74 \\
$\quad$ & \\
Wage/Salary (Dummy) & & \\
Unemployed (Dummy) & 0.90 & 0.90 \\
Not in the Labor Force (Dummy) & 0.11 & 0.19 \\
Years at Job & 0.25 & 0.31 \\
Household Wealth & 7.66 & 5.57 \\
Annual Household Asset Income & 114,951 & 140,518 \\
Sample Size & 587 & 907 \\
\hline
\end{tabular}

Table A2.

Summary Statistics, Sample Means, by Exit and No Exit.

\begin{tabular}{lcc} 
& \multicolumn{2}{c}{ Self-Employment Exit } \\
& No Exit & Exit \\
\hline High School Dropout & 0.08 & 0.11 \\
High School Graduate & 0.28 & 0.28 \\
Some College & 0.27 & 0.31 \\
College Graduate & 0.36 & 0.30 \\
Age & 45.07 & 42.30 \\
Married & 0.78 & 0.68 \\
Number of Children & 0.95 & 0.84 \\
Number of Persons in Household & 3.17 & 3.14 \\
Urban Resident & 0.74 & 0.78 \\
Immigrant & 0.07 & 0.09 \\
Years Since Immigration & 1.33 & 1.66 \\
In Sample Business Entry & 0.22 & 0.47 \\
& & \\
Years Owned Business & 11.16 & 7.42 \\
Household Wealth & 285,727 & 187,515 \\
Annual Household Asset Income & 1,518 & 880 \\
Sample Size & 18,113 & 2,448 \\
\hline
\end{tabular}


Table A3.

Decomposition of Entry into Self-Employment (Pooled Coefficients)

\begin{tabular}{|c|c|c|}
\hline & Mexican-Hispanics & Other-Hispanics \\
\hline White entry rate & 0.0265 & 0.0265 \\
\hline Hispanic entry rate & 0.0236 & 0.0340 \\
\hline Hispanic/White gap & 0.0029 & -0.0075 \\
\hline \multicolumn{3}{|l|}{ Contributions from racial differences in: } \\
\hline \multirow[t]{3}{*}{ Educational Attainment } & 0.0032 & 0.0012 \\
\hline & $(0.0007)$ & $(0.0003)$ \\
\hline & $111.21 \%$ & $-15.40 \%$ \\
\hline \multirow[t]{3}{*}{ Age } & -0.0013 & -0.0015 \\
\hline & $(0.0003)$ & $(0.0002)$ \\
\hline & $-45.54 \%$ & $20.20 \%$ \\
\hline \multirow[t]{3}{*}{ Family Composition } & 0.0002 & 0.0003 \\
\hline & $(0.0007)$ & $(0.0003)$ \\
\hline & $7.42 \%$ & $-3.44 \%$ \\
\hline \multirow[t]{3}{*}{ Urban Resident } & 0.0000 & 0.0000 \\
\hline & $(0.0002)$ & $(0.0003)$ \\
\hline & $0.17 \%$ & $-0.12 \%$ \\
\hline \multirow[t]{3}{*}{ Nativity and Years in the U.S. } & -0.0047 & -0.0048 \\
\hline & $(0.0017)$ & $(0.0017)$ \\
\hline & $-163.90 \%$ & $64.65 \%$ \\
\hline \multirow[t]{3}{*}{ Unemployed or NILF in Previous Year } & -0.0011 & -0.0003 \\
\hline & $(0.0002)$ & $(0.0002)$ \\
\hline & $-36.48 \%$ & $4.24 \%$ \\
\hline \multirow[t]{3}{*}{ Job Tenure } & -0.0010 & -0.0008 \\
\hline & $(0.0002)$ & $(0.0002)$ \\
\hline & $-36.11 \%$ & $10.37 \%$ \\
\hline Household Wealth $_{\mathrm{t}-1}$ and & 0.0020 & 0.0018 \\
\hline \multirow[t]{2}{*}{ Annual Asset Income ${ }_{t-1}$} & $(0.0004)$ & $(0.0004)$ \\
\hline & $70.31 \%$ & $-23.71 \%$ \\
\hline
\end{tabular}

Note: Standard errors are reported in parentheses below contribution estimates. 
Table A4.

Decomposition of Exit Out of Self-Employment (Pooled Coefficients)

\begin{tabular}{|c|c|c|}
\hline & Mexican Hispanics & Other Hispanics \\
\hline White exit rate & 0.11346 & 0.11346 \\
\hline Hispanic exit rate & 0.20457 & 0.18635 \\
\hline Hispanic/White gap & -0.09112 & -0.07289 \\
\hline \multicolumn{3}{|c|}{ Contributions from racial differences in: } \\
\hline \multirow[t]{3}{*}{ Educational Attainment } & -0.00492 & -0.00272 \\
\hline & $(0.00473)$ & $(0.00204)$ \\
\hline & $5.40 \%$ & $3.73 \%$ \\
\hline \multirow[t]{3}{*}{ Age } & -0.00523 & -0.00090 \\
\hline & $(0.00129)$ & $(0.00125)$ \\
\hline & $5.74 \%$ & $1.23 \%$ \\
\hline \multirow[t]{3}{*}{ Family Composition } & -0.00956 & -0.00826 \\
\hline & $(0.00341)$ & $(0.00196)$ \\
\hline & $10.49 \%$ & $11.34 \%$ \\
\hline \multirow[t]{3}{*}{ Urban Resident } & -0.00119 & -0.00262 \\
\hline & $(0.00079)$ & $(0.00170)$ \\
\hline & $1.30 \%$ & $3.59 \%$ \\
\hline \multirow[t]{3}{*}{ Nativity and Years in the U.S. } & 0.00587 & 0.00755 \\
\hline & $(0.00808)$ & $(0.01068)$ \\
\hline & $-6.44 \%$ & $-10.36 \%$ \\
\hline \multirow[t]{3}{*}{ Years Owning Business } & -0.00619 & -0.00849 \\
\hline & $(0.00113)$ & $(0.00119)$ \\
\hline & $6.79 \%$ & $11.65 \%$ \\
\hline \multirow[t]{3}{*}{ In Sample Business Entry } & -0.01084 & -0.01190 \\
\hline & $(0.00126)$ & $(0.00132)$ \\
\hline & $11.89 \%$ & $16.33 \%$ \\
\hline Household Wealth $_{\mathrm{t}-1}$ and & -0.00543 & -0.00354 \\
\hline \multirow[t]{2}{*}{ Annual Asset Income ${ }_{t-1}$} & $(0.00203)$ & $(0.00138)$ \\
\hline & $5.96 \%$ & $4.86 \%$ \\
\hline
\end{tabular}

Note: Standard errors are reported in parentheses below contribution estimates. 